\title{
Rhetoric, persuasion, and interpretation in international law
}

Link to publication record in Manchester Research Explorer

\section{Citation for published version (APA):}

Scobbie, I., Bianchi, A. (Ed.), Peat, D. (Ed.), \& Windsor, M. (Ed.) (2015). Rhetoric, persuasion, and interpretation in international law. In Interpretation in international law (1 ed., Vol. 1, pp. 61-77). Oxford University Press.

\section{Published in:}

Interpretation in international law

\section{Citing this paper}

Please note that where the full-text provided on Manchester Research Explorer is the Author Accepted Manuscript or Proof version this may differ from the final Published version. If citing, it is advised that you check and use the publisher's definitive version.

\section{General rights}

Copyright and moral rights for the publications made accessible in the Research Explorer are retained by the authors and/or other copyright owners and it is a condition of accessing publications that users recognise and abide by the legal requirements associated with these rights.

\section{Takedown policy}

If you believe that this document breaches copyright please refer to the University of Manchester's Takedown Procedures [http://man.ac.uk/04Y6Bo] or contact uml.scholarlycommunications@manchester.ac.uk providing relevant details, so we can investigate your claim.

\section{OPEN ACCESS}




\title{
3
}

\section{Rhetoric, Persuasion, and Interpretation in International Law}

\author{
Iain Scobbie*
}

\section{The Art of Rhetoric}

All games have rules, and all games have strategies for effective play. Ultimately, the aim is to win the game. Legal argumentation inevitably calls upon players to interpret the facts, rules, and concepts upon which their argument rests. The art of rhetoric sets out ground rules for successful argumentative, and thus interpretative, practice, and provides tactics and strategies by which this may be achieved-although, as in all games, success is never guaranteed for any specific player. All lies in the knowledge and skill of the player and the choices he makes.

Rhetoric has ancient roots, and for centuries its study was a standard component of a university education in the humanities. For example, Adam Smith, the eighteenth century economist and moral philosopher, also lectured on rhetoric at the University of Glasgow. A student's notes of the lecture series Smith delivered in 1762-63 survives, and records Smith as saying:

[It is] however from the consideration of these [tropes and figures of speech], and the divisions and subdivisions of them, that so many systems of retorick both ancient and modern have been formed. They are generally a very silly set of books and not at all instructive. ${ }^{1}$

Smith's antipathy to other rhetorical works flowed from his view that rhetoric should be a form of plain speaking-'Perspicuity of stile requires not only that the expressions we use should be free from all ambiguity proceeding from

* My interest in legal reasoning was first stimulated when I was an undergraduate by the late Neil MacCormick, then Regius Professor of Public Law and the Law of Nature and Nations at the University of Edinburgh, who taught me jurisprudence. I first came across a reference to Chaïm Perelman in one of his essays, in whose work I became very interested during my doctoral studies at the University of Cambridge under the tutelage of Philip Allott and Eli Lauterpacht. To all three, I owe thanks for their support and indulgence. For their indulgence and patience, I should also thank the editors, and, for his support, my colleague Jean d'Aspremont.

1 Adam Smith, Lectures on Rhetoric and Belles Lettres (Clarendon Press 1983: ed JC Bryce) 26, [i.v.59]. For 'retorick', read 'rhetoric': the student's spelling is inconsistent and, at times, archaic throughout his notes. 
synonimous words but that the words should be natives if I may say so of the language we speak in'. ${ }^{2}$ He abhorred ornamentation in argument which he thought masked and obscured meaning:

What are generally called ornaments or flowers in language, as allegoricall, metaphoricall and such like expressions are very apt to make ones stile dark and perplex'd. Studying much to vary the expression leads one also frequently into a dungeon of metaphorical obscurity. ${ }^{3}$

Smith's injunction that rhetorical style books are 'not at all instructive' is an over-statement. Yet rhetoric is often viewed warily, perceived as a perversity of true argument, and as the conscious presentation of false and florid argument which seeks to distort or mask the truth of a situation rather than examine it dispassionately. There is no doubt that there is some degree of truth in this. The orations of, for instance, politicians and their spokesmen can often be slick, self-serving, and emotive, ${ }^{4}$ attempting to justify the unjustifiable and unpalatable, but there is a more serious aspect to the art of rhetoric upon which we shall focus. As Chaïm Perelman, without doubt the leading theorist of rhetoric in the twentieth century, argued:

Rhétorique... n'est pas l'art de bien parler, dans un style fleuri et ampoulé: c'est l'art de persuader et de convaincre, qui peut se manifester par un discours ou par un écrit et qui, pour les juristes, consiste essentiellement dans l'usage de l'argumentation. ${ }^{5}$

\section{Rhetoric-Legal Argumentation as an Interpretative Mechanism}

From the early twentieth century onwards, there was a resurgence of philosophical interest in the art of rhetoric. In 1936, the literary critic Ivor A Richards was pessimistic about the contemporary status of rhetoric in academic circles:

So low has Rhetoric sunk that we would do better just to dismiss it to Limbo than to trouble ourselves with it - unless we can find reason for believing that it can become a study that will minister successfully to important needs. ${ }^{6}$

2 Smith, Lectures on Rhetoric and Belles Lettres, 3, [i.i.1] (textual apparatus suppressed).

3 Smith, Lectures on Rhetoric and Belles Lettres, 8, [i.i.14] (textual apparatus suppressed). For Smith's views on plain style, see generally Lecture 2: 3-8.

${ }^{4}$ For an incisive introduction to political rhetorical technique, see Max Atkinson, Our Masters' Voices: The Language and Body Language of Politics (Routledge 1984).

5 Chaïm Perelman, Le Champ de l'argumentation (Presses Universitairies de Bruxelles 1970) 139: 'rhetoric... is not the art of speaking well in a high-flown flowery style: it is the art of persuading and convincing, whether in speech or in writing, and which for lawyers lies essentially in the use of argumentation'. See also Chaïm Perelman and Lucie Olbrechts-Tyteca, The New Rhetoric: A Treatise on Argumentation (University of Notre Dame Press 1969) 6-9, and [96], 450-9.

${ }^{6}$ Ivor A Richards, The Philosophy of Rhetoric (OUP 1936) 3. 
Richards was influential in redeeming the reputation of rhetoric in literary and philosophical circles, and from the 1950s there was also an upsurge in interest of the role that rhetoric could play in practical reason generally, and in law in particular, by theorists such as Perelman and Lucie Olbrechts-Tyteca, Stephen Toulmin, ${ }^{7}$ and Theodor Viehweg. ${ }^{8}$ The most prolific and significant author in this discipline, which he termed 'la nouvelle rhétorique', or 'the new rhetoric', was Perelman. ${ }^{9}$

A central and common theme in modern rhetorical theory is the ambiguity and malleability of the meaning of natural language, as opposed to the absolute referents of the formal languages of logic and mathematics. ${ }^{10}$ This might have been influenced, at least in early twentieth century literary circles, by the serious playfulness of the desire to disrupt readers' confidence in the apparent certainties of language by modernist authors such as TS Eliot, James Joyce, and Gertrude Stein. Joyce, particularly in Finnegans Wake (1939), and Stein, especially in her work preceding the fame, and income, which accrued to her with the publication of The Autobiography of Alice B Toklas (1933), trashed conventional expectations about the stability of language and the accessibility of its meaning:

Stein's true radical legacy lay in her insistence on showing how words and their meanings could be undone; she took it as her right that she had the freedom to use words exactly as she pleased, and in doing so she undermined the relation between words and the world. ${ }^{11}$

7 See Stephen Toulmin, The Uses of Argument (CUP 1958).

8 Theodor Viehweg, Topics and the Law: A Contribution to Basic Research in Law (Peter Lang 1993: $\operatorname{tr}$ WC Durham). The first German edition of Viehweg's Topik und Jurisprudenz was published in 1953. Durham's translation is of the fifth edition which was published in 1973.

9 Chaïm Perelman and Lucie Olbrechts-Tyteca collaborated to produce the foundational work and most extensive statement of Perelman's 'new rhetoric': La Nouvelle Rhétorique: Traité de l'argumentation (Presses Universitaires de France 1958); The New Rhetoric: A Treatise on Argumentation (University of Notre Dame Press 1969: tr John Wilkinson and Purcell Weaver). Perelman subsequently published a condensed version of The New Rhetoric: L'empire Rhétorique: Rhétorique et Argumentation (Vrin 1977); The Realm of Rhetoric (University of Notre Dame Press 1982: tr William Kluback). Other important works by Perelman include: Le Champ de l'argumentation; Justice et Raison (2nd edn, Editions de l'Université de Bruxelles 1972); Logique Juridique: Nouvelle Rhétorique (Dalloz 1976); The New Rhetoric and the Humanities: Essays on Rhetoric and its Applications (Reidel 1979); Justice, Law, and Argument: Essays on Moral and Legal Reasoning (Reidel 1980). There are numerous commentaries on Perelman's work. See eg Ray Dearin (ed), The New Rhetoric of Chaïm Perelman: Statement and Response (University Press of America 1989); Benoît Frydman and Michel Meyer (eds), Chaïm Perelman (1912-2012): de la Nouvelle Rhétorique à la Logique Juridique (Presses Universitaires de France 2012); Alan Gross and Ray Dearin, Chaïm Perelman (SUNY Press 2003); Guy Haarscher and León Ingber, Justice et Argumentation: Essais à le Mémoire de Chaïm Perelman (Editions de l'Université de Bruxelles 1986); William Kluback, 'The Implications of Rhetorical Philosophy' (1986) 5 Law \& Phil 315; and Roland Schmetz, L'argumentation selon Perelman (Presses Universitaires de Namur 2000). A good brief critical account of Perelman's theory is Robert Alexy, $A$ Theory of Legal Argumentation (Clarendon Press 1989: tr Ruth Adler and Neil MacCormick) 155-76.

10 See Charles K Ogden and Ivor A Richards, The Meaning of Meaning (Kegan Paul 1946).

11 Lucy Daniel, Gertrude Stein (Reaktion Books 2009) 190. A forensic examination of Stein's conscious effacement of 'meaning' is Ulla Dydo, Gertrude Stein: the Language that Rises 1923-1934 (Northwestern University Press 2003) 12:

she challenges our capacity to read and our expectations of what written words and sentences are, what they do and how they do it. Her writing calls for radical redefinition of genre, representation, language, reading, and writing. 
Language, and especially the manipulation of language and its meaning, reference, and extension - in other words, the interpretation of terms - is fundamental to rhetoric because rhetoric examines the techniques of argumentation which aim to persuade someone, or some people or group, to take some action or make some decision. These attempted acts of persuasion are constructed from natural language:

Pour communiquer avec son auditoire, l'orateur considérera le langage comme un vaste arsenal dans lequel il choisira les moyens qui lui semblent les plus favorables à sa thèse. ${ }^{12}$

Not all theorists consider that persuasion is the sole aim of rhetoric-for instance, Richards argues that rhetoric also has an expository function 'which is concerned to state a view, not to persuade people to agree or to do anything more than examine it.'. ${ }^{13}$ White sees three elements in rhetoric-the Aristotelian enthymeme which tries to establish probabilities, 'the ignoble art of persuasion', and his notion of constitutive rhetoric. ${ }^{14}$ We are not concerned here with these variants, but with rhetoric as a form of practical reasoning, particularly as this is employed in international legal argumentation and interpretation.

Legal argumentation is a specialized form of rhetoric which is principally concerned with interpretation - the interpretation of facts, of legal terms and concepts, of meaning and value, of what the law is meant to achieve, of what the parties to a case want the law to 'mean', or of what the parties to a transaction aim to achieve. Legal argument is essentially instrumental because it aims to have a practical effect, but by its nature it aims at securing the assent or adhesion of those to whom the argument is addressed rather than demonstrating the truth of the proposition or interpretation advanced. This is because rhetoric comprises non-compelling argumentation which argues from probabilities and possibilities rather than from certainties.

Perelman claims that to say that a text is clear in a given case is only to indicate that its interpretative possibilities were not discussed. Such an impression of clarity may be less the expression of good understanding than a failure of imagination. ${ }^{15}$ He sees litigation as an eristic dialogue, which occurs when there is a third party who decides between the arguments presented, in which counsel present their arguments with a complete indifference to the truth. Their function is to perplex their adversary and win the argument. ${ }^{16}$ This view is too schematic: while litigation might well be seen as the central case of legal oratory, legal rhetoric is employed in many other interpretative situations-for example, in advising clients, arguing

12 Perelman, Logique Juridique, [60], 119: 'To communicate with his audience, the orator will see language as a vast arsenal from which he will choose the means which seem to him the most favourable to his proposition.'

13 Richards, The Philosophy of Rhetoric, 24.

14 James Boyd White, 'Law as Rhetoric, Rhetoric as Law: The Arts of Cultural and Communal Life' (1985) 52 U Chi L Rev 684.

15 Perelman, Logique Juridique, [25], 36.

16 Perelman and Olbrechts-Tyteca, The New Rhetoric, [8], 38; Perelman, The Idea of Justice and the Problem of Argument (Kegan Paul 1963) 101, 161-7; Perelman, Justice et Raison, 221; and Perelman, Logique Juridique, [7], 7, [50], 101-2, [71], 135. 
whether proposed legislation or agreements are consonant with existing law, or in constructing academic commentaries.

\section{Blame it all on the Ancient Greeks}

The art of rhetoric has deep historic and functional roots. Hand in hand with the emergence of democracy in Athens and other Greek cities in the fifth century BCE came the study of rhetoric: participation in government by adult male citizens required that they must be able to speak effectively in public. Similarly, as there were no professional lawyers, if a citizen were involved in legal proceedings, he was expected to be able to speak for himself. The approaches to the practice of rhetoric adopted were, however, divisive. On the one hand were the Sophists, professional teachers of rhetoric who taught their students how to marshal arguments, divide speeches into sections, and choose and combine words and phrases. ${ }^{17}$ Socrates and Plato were hostile to this approach. In Gorgias, ${ }^{18}$ Plato attacked Sophist rhetoric as immoral and dangerous, being more a manipulative form of flattery than the pursuit of truth. He later moderated his views in Phaedrus, ${ }^{19}$ arguing that it could be a useful tool of persuasion in the hands of a true philosopher.

Aristotle, on the other hand, took the view that rhetoric was a morally neutral form of communication, with its persuasive value being dependent on:

the truth and logical validity of what is being argued; the speaker's success in conveying to the audience the perception that he or she can be trusted; and the emotions that a speaker is able to awaken in an audience to accept the views advanced and act in accordance with them. ${ }^{20}$

Aristotle drew a clear line between logic and rhetoric. He saw logic as the technique of arguing from truths or certainties to render an answer which is equally true, while rhetoric comprises the techniques of persuasion which may be used to structure argument over a range of subjects where the issue under discussion is debatable- 'we debate about things that seem to be capable of admitting two possibilities; for no one debates things incapable of being different either in past or future or present, at least not if they suppose that to be the case; for there is nothing more [to say]'.21 Thus rhetoric deals with arguing from possibilities and probabilities, rather than the demonstration of the certainties of logic. Nonetheless, for Aristotle, a rhetorical argument should be logical in structure, proceeding by way of enthymemes, that is by employing rhetorical syllogisms which use probabilities rather than truths as premises:

17 For selective examples of Sophists' work, see Michael Gagarin and Paul Woodruff (eds), Early Greek Political Thought from Homer to the Sophists (CUP 1995) 173-311.

18 Various modern translations and editions are available. See eg Plato Gorgias (OUP 2008: ed and tr Robin Waterfield).

19 See eg Plato, Phaedrus (OUP 2002: ed and tr Robin Waterfield).

20 Aristotle, On Rhetoric: A Theory of Civic Discourse (OUP 1991: ed and tr George Kennedy) ix.

21 Aristotle, On Rhetoric, 41 (Book I, Chapter 2.12). 
few of the premises from which rhetorical syllogisms are formed are necessarily true (most of the matters with which judgment and examination are concerned can be other than they are; for people deliberate and examine what they are doing, and [human] actions are all of this kind, and none of them [are], so to speak, necessary) ... it is evident that [the premises] from which enthymemes are spoken are sometimes necessarily true but mostly true [only] for the most part... enthymemes are derived from probabilities. ${ }^{22}$

The aim of rhetoric is persuasion, and a rhetorical argument principally takes the form of an exercise in practical reason. Aristotle argued that there are three types of rhetoric: the deliberative, the judicial, and the epideictic. The first concerns what should be done, while the second examines what happened in the past; both are aimed at making decisions and thus are forms of practical reason. Epideictic rhetoric is a speech of praise or blame but which does not call for any immediate action by the audience. ${ }^{23}$

In constructing an argument, the main resource the speaker should draw upon is the topos (topic), which 'literally means "place", metaphorically that location or space in an art where a speaker can look for "available means of persuasion"' ${ }^{24}$ Topoi (topics) can be of two forms: those that are general or common to a wide range of substantive issues, and those which are specific to a given field. ${ }^{25}$ In deliberative and judicial rhetoric, the aim of the speaker is to persuade his audience:

Persuasion occurs through the arguments [logoi] when we show the truth or apparent truth from whatever is persuasive in each case. ${ }^{26}$

Accordingly, the Aristotelian concept of rhetoric was practical, and differed from the fine speeches of the Sophists which were often aimed at simply arousing the emotions of the audience.

\section{Rediscovering the Past-The Resurgence of Rhetoric in the Twentieth Century}

Perelman and Olbrechts-Tyteca, Toulmin, and Viehweg were all firmly rooted in the Aristotelian notion of rhetoric, ${ }^{27}$ rather than that of the Sophists, but they also reacted against a Cartesian world view of systematization and logical deduction:

When agreement can easily be reached by means of calculation, measuring, or weighing, when a result can be either demonstrated or verified, nobody would think of resorting to

22 Aristotle, On Rhetoric, 42-43 (Book I, Chapter 2.14).

23 Aristotle, On Rhetoric, 47-50 (Book I, Chapter 3). On this genre of rhetoric, see Perelman and Olbrechts-Tyteca, The New Rhetoric, [11], 47-51; Perelman, Realm of Rhetoric, 19-20.

24 Aristotle, On Rhetoric, 45 (translator's note).

25 Aristotle, On Rhetoric, 46-47 (Book I, Chapters 21-22).

26 Aristotle, On Rhetoric, 39 (Book I, Chapter 2.6).

27 See eg Perelman and Olbrechts-Tyteca, The New Rhetoric, 4-9; Perelman, The Idea of Justice and the Problem of Argument, 161-67; Viehweg, Topics and the Law, 7-12; and Giovanni Damele, 'Aristotle et Perelman: L’Ancienne et la Nouvelle Rhétorique' (28 October 2009) <http://papers. ssrn.com/sol3/papers.cfm?abstract_id=2167799> accessed 7 August 2014. 
dialectical discussion. The latter concerns only what cannot be so decided and, especially, disagreements about values. In fact, in matters of opinion, it is often the case that neither rhetoric nor dialectic can reconcile all the positions that are taken. ${ }^{28}$

Perelman's fundamental critique regarding the role of logic in practical decision-making revolves around the notion that formal logical systems are isolated from any context-'un système purement formel, et un jeu avec ses règles, n'étant pas des moyens visant à réaliser une fin sociale'. ${ }^{29}$ This is a point reinforced graphically by Toulmin. ${ }^{30}$

Perelman argues that only formal logical arguments can compel a conclusion, but that outside mathematics, the conditions required in order that such an argument may be asserted are absent. A formal logical argument may only take place within a system which is complete, contains no internal contradictions, and where the terms are univocal and unambiguous. ${ }^{31} \mathrm{He}$ argues that these requirements are not met in any legal system - in particular, natural language cannot fulfil the requirement of univocity and is inherently ambiguous. ${ }^{32}$ Conversely, because the terms employed in a logic calculus are determinate, univocal, and unambiguous, there can be no room for their interpretation in a formal system. Simply because law is expressed in natural language, propositions are open to interpretation and thus law is not amenable to systematization as a formal logical system:

That language combines within itself an almost incomprehensible abundance of continuously varying horizons of understanding becomes increasingly clear to us today... [N]atural language constantly takes up inventive new viewpoints. In this way it proves its fertility and pliability, but at the same time unremittingly jeopardizes the deductive system. Concepts or propositions which turn up in the natural language are unreliable for purposes of system building. If one is dependent upon natural language, as one presumably always is in the realm of law, then one hovers as a systematizer in constant danger of being unconsciously led with gentle force by its interpretations and reinterpretations. One has already lost the game if one refers in case of need to ordinary language, an occurrence which takes place continuously in legal practice and, reasonably enough, must frequently occur. ${ }^{33}$

28 Perelman, The New Rhetoric and the Humanities, 13; Perelman, Justice, Law, and Argument, $143-4$.

29 Perelman, Logique Juridique, [34], 59: 'a purely formal system, and games with its rules, are not ways which are aimed at achieving a social purpose'; Perelman and Olbrechts-Tyteca, The New Rhetoric, [1], 13-14.

30 Toulmin, The Uses of Argument, 146-210.

31 Perelman, Justice, Law, and Argument, 137. Perelman, however, immediately qualifies the requirement of completeness, claiming that this can only be fulfilled in very simple systems: 'There is a general tendency to say that every system having a certain richness of expression is necessarily incomplete. This means that we can show that sufficiently rich systems necessarily contain undecidable propositions which can be neither affirmatively nor negatively demonstrated' (138). See also Perelman, The Idea of Justice and the Problem of Argument, 99-100.

32 This is a recurring theme throughout Perelman's work. See eg Perelman and Olbrechts-Tyteca, The New Rhetoric, [1], 13-14, [30] 120-3, [33] 130-3; Perelman, The Idea of Justice and the Problem of Argument, 89-90, 95 et seq, 99-100, 114-15, 143-50; Perelman, Justice et Raison, 81 et seq; Perelman, Logique juridique, [24], 34-6, [56], 114-15; Perelman, Justice, Law, and Argument, 95-106, 126, 137-8.

33 Viehweg, Topics and the Law, 77-8. See 69-82 generally. 
Perelman repeatedly illustrates the non-univocity of natural language using the notion of apparent tautology such as 'boys will be boys' or 'business is business'. To give these propositions meaning, different interpretations must be given to the repeated terms whereas in formal systems they would be meaningless because of the systemic requirement of the principle of identity which mandates that terms must be univocal. ${ }^{34}$

Accordingly, because the determinative nature of a formal logical system is lacking, rhetoric is the study of non-compelling argumentation. It analyses methods of argument in which the conclusion is not simply a syllogistically valid deduction from given premises. Rather the conclusion depends on the appreciation of the relative strengths of the arguments adduced and, ultimately, requires a non-arbitrary power of decision being vested in someone to determine which argument is to succeed. The outcome reached thus depends on choice, and not simply on logical proof. ${ }^{35}$

\section{The Elements of Effective Rhetoric-Audience, Topics, Choice}

In modern rhetorical theory, the function of argument is to persuade an audience to take action or make a decision. The concept of the audience is most developed in Perelmanien theory. He claims that the worth of an argument is dependent on the audience (or auditor) to which it is presented. A successful argument is simply one that persuades the relevant audience. There is an infinite variety of audiences which may be addressed by a rhetor, ${ }^{36}$ but Perelman's main dichotomy is drawn between particular and general audiences. Particular audiences represent essentially sectional interests, whereas Perelman sees the universal audience as objective. ${ }^{37}$ The new rhetoric aims to describe argumentative techniques which are valid for all audiences, or at least all audiences composed of rational and competent people. Objective argument aims at transcending the contingencies inherent in sectional interests, thus gaining the adherence of the universal audience. ${ }^{38}$

\footnotetext{
34 See eg Perelman and Olbrechts-Tyteca, The New Rhetoric, [51], 216-18, 442-3; Perelman, Logique Juridique, [56], 114-16; Perelman, Justice, Law, and Argument, 97, 126.

35 See eg Perelman and Olbrechts-Tyteca, The New Rhetoric, [13], 59-62; Perelman, The Idea of Justice and the Problem of Argument, 101; Perelman, Justice et Raison, 220; Perelman, Justice, Law, and Argument, 129, 150.

36 Perelman, Logique Juridique, [52], 107. Following Lyndel Prott, 'rhetor', a now generally obsolete term, shall be used to refer to someone who engages in rhetoric, whether spoken or written, with the aim of persuading an audience: The Latent Power of Culture and the International Judge (Professional Books 1979) 125. The most obvious alternative, 'rhetorician', tends now to have pejorative overtones which are best avoided.

37 Perelman and Olbrechts-Tyteca, The New Rhetoric, [7], 31-5, [15], 65-6.

38 Perelman and Olbrechts-Tyteca, The New Rhetoric, [6]-[7], 26-35; Perelman, Logique Juridique, [52], 107.
} 
Nonetheless, Perelman argues that the universal audience can only be a construct of the rhetor. ${ }^{39}$ It is a conceptual category, rather than a material entity, but it is nonetheless useful because:

By thus generalising the idea of the audience, we can ward off Plato's attack against the rhetoricians for showing greater concern for success than for the truth. To this criticism we can reply... that the worth of an argument is not measured solely by its efficacy but also by the quality of audience at which it is aimed. Consequently, the idea of a rational argumentation cannot be defined in abstracto, since it depends on the historically grounded conception of the universal audience. ${ }^{40}$

Perelman's notion of the universal audience has been criticized as philosophically problematic, requiring the rhetor to construct an objective model on the basis of his own subjective understanding. ${ }^{41}$

This controversy need not detain us, as Perelman acknowledges that a rhetor may substitute an elite or, more importantly, a specialist audience for the universal. The latter is one whose members have specialist knowledge of a given area and which therefore may be assimilated to the universal in that field-for instance, the scientist addressing other scientists. ${ }^{42}$ Specialized disciplines, such as law, contain recognized modes of argument, techniques, predispositions, as well as substantive content which can act as the foundations for an argument. ${ }^{43}$ Perelman, however, cautions:

Reasons considered good at one period of time and one milieu are not in another; they are socially and culturally conditioned as are the convictions and aspirations of the audience they must convince. ${ }^{44}$

Following Aristotle, central to modern theories of rhetoric is the notion of topics-'Topics is a technique of problemoriented thought that was developed by rhetoric' ${ }^{45}$ For Aristotle, a topic was a metaphor for the place where a speaker can look for materials or arguments which are persuasive to his thesis. Durham illustrates this metaphor with specific reference to the use of topical argument in legal research:

The standard approach to researching a legal problem in common law settings is to identify relevant cases. A good lawyer has a sense for the topography of case law. To use terminology reminiscent of Aristotle, he or she knows the 'region' where relevant arguments (the reasoning of specific cases) can be found... The instinctive common law approach is

39 Perelman and Olbrechts-Tyteca, The New Rhetoric, [4], 19-23, [7], 32-3; Perelman, Logique Juridique, [52]-[53], 107-9.

40 Perelman, The New Rhetoric and the Humanities, 14. See also Perelman and Olbrechts-Tyteca, The New Rhetoric, [6]-[7], 30-6; Perelman, Justice et Raison, 100-3.

41 For discussions of this criticism, see Alexy Aarnio, 'Argumentation Theory and Beyond: Some Remarks on the Rationality of Legal Justification' (1983) 14 Rechtstheorie 385, 391-2; Gross and Dearin, Chä̈m Perelman, 32-9; Allen Scult, 'Perelman's Universal Audience: One Perspective' in Dearin, The New Rhetoric of Chaïm Perelman, 153; Schmetz, L'argumentation selon Perelman, 47-88.

42 Perelman and Olbrechts-Tyteca, The New Rhetoric, [7], 33-4.

43 Perelman and Olbrechts-Tyteca, The New Rhetoric, [26], 99-104.

44 Perelman, Justice, Law, and Argument, 131. $\quad 45$ Viehweg, Topics and the Law, 1. 
to start with a problem, and then identify cases that involve maximally similar problems in order to identify arguments and insights that bear on the problem at hand. ${ }^{46}$

International law, to borrow Tammelo's terminology, is a rhetorically oriented rather than an axiom-oriented system because it is neither codified nor based on precisely formulated basic principles which can operate as major premises in deductive syllogistic reasoning. ${ }^{47}$ Topics, however, aid in the consolidation of this system where legal materials and opinion consolidate around settled points-'a topical approach is our principal technique of logically managing opinions and, especially, of turning a mass of opinions into an ordered system'. ${ }^{48}$ In this light, it has been argued that commonly used, or established, interpretative methods and canons are essentially 'rival meta-topoi we invoke in the process of determining how various other rhetorical constructs (statutes, prior judicial opinions, etc) should be interpreted' ${ }^{49}$

The rhetor's aim is to persuade his audience to adhere to his conclusions. To be effective, he must build on propositions or premises to which the audience already agrees. ${ }^{50}$ This provides a general premise for the development of the rhetor's argument. Perelman refers to these, fairly indiscriminately, as loci, commonplaces (lieux communs) or topics, ${ }^{51}$ and argues that the audience and the discourse interact. The rhetor adapts his discourse to the audience by hooking his argument onto a proposition the audience already accepts in order to show that his conclusion is a development from that initial position. The audience is not a tabula rasa, but already accepts certain facts and presumptions, and has beliefs and opinions, including views on legitimate argumentative techniques. The aim is to transfer to the conclusion the audience's existing adhesion or agreement to the premise. ${ }^{52}$ Thus topics, as starting points for argument, play a role which is

46 Viehweg, Topics and the Law, xxiii-xxiv (translator's foreword).

47 See Ilmar Tammelo, 'On the Logical Openness of Legal Orders' (1959) 8 Am J Comp L 187, 187-188; Ilmar Tammelo, 'The Law of Nations and the Rhetorical Tradition of Legal Reasoning' (1964) 13 Indian YB Int'l Aff 227, 252-254; Samuel Stoljar, 'System and Topoi' (1981) 12 Rechtstheorie 385; Samuel Stoljar, 'Paradigms and borderlines' (1982) 13 Rechtstheorie 133. The rhetorical nature of all legal systems is, of course, a key issue emphasized by Perelman and Olbrechts-Tyteca, and Viehweg.

48 Stoljar, 'System and Topoi', 389.

49 Viehweg, Topics and the Law, xxii, xxiv-xxv (translator's foreword), 30.

50 Perelman terms this an 'object of agreement', which fall into two categories: those relating to the real (facts, truths, and presumptions), and those relating to the preferable (values, hierarchies, and lines of agreement on the preferable). See Perelman and Olbrechts-Tyteca, The New Rhetoric, [15]-[28], 66-114, and Part Two, Chapter One in general.

51 'Topics' is the term adopted throughout this chapter. Perelman breaks with classical rhetorical tradition by using the term loci only in relation to general premises which can serve as the basis for values or hierarchies. These may be general or special: a general locus is an affirmation regarding a value which is presumed to be relevant in all circumstances whatsoever, whereas a special locus concerns what is preferable in a given situation. As loci become more specific in character, there is a gradual shift from loci which may serve as general argumentative premises, to loci which Perelman sees as agreements on actual values or value hierarchies: Perelman and Olbrechts-Tyteca, The New Rhetoric, [21], 83-5, [24]-[25], 95-6.

52 See Perelman and Olbrechts-Tyteca, The New Rhetoric, [10]-[11], 45-51, [15] 65-6, [25] 96, [27] 104-10, [44] 189; Perelman, Logique Juridique, [53]-[54], 109-11. Perhaps the best exposition of the 'audience is not a tabula rasa' notion is in Perelman, Justice, Law, and Argument, 169-70. 
analogous to that of axioms in formal logical systems. They differ from axioms in that the adhesion which topics attract is not based on evidence but often on their ambiguity and the possibility that they might be interpreted and applied in different ways. Rhetorical arguments, starting from the same premises, can end in different, or even opposed, conclusions. There is often more agreement on the initial starting topic of an argument than on its ultimate outcome. ${ }^{53}$

A clear illustration of this point may be made by reference to Perelman's concept of abstract (or universal) values. Certain values are thought to be universal-such as the good, the true, the beautiful — but they can only claim to be universal values because they are abstract. The universal audience can only adhere to such values as long as their content is relatively vague: as specific content is attributed to an abstract value, only the adherence of particular audiences is possible because disagreements can reasonably arise regarding the specific implications of, for instance, beauty. ${ }^{54}$

However, universal values have a persuasive function: they may be used to justify a choice or decision by operating as an empty frame of reference. For instance, Perelman argues that the adoption of the Universal Declaration of Human Rights proceeded on this basis. By inserting abstract values as empty frames within the text, States with different ideological affiliations could interpret the Universal Declaration in different ways, because its content was free from specific reference. Perelman sees this as useful. Although agreement on the text was only possible using empty frames and abstract values, a single text was produced which could serve as the basis for further action. Use of this methodology also ensured the continuity of dialogue. ${ }^{55}$

This also illustrates the point that an audience may be composite because its members adhere to diverse opinions. The rhetor must seek to persuade each subset of the audience, and thus cumulation of argument is a characteristic of rhetorical reasoning. This can lead to the adduction of apparently inconsistent arguments, because each is aimed at a different sector of the audience. Perelman sees this strategy not as inconsistent, but as the use of redundancy, because the acceptance of one argument makes the others unnecessary. This type of redundancy is fully justified in Perelman's conception of rhetoric. ${ }^{56}$

The predispositions of the audience also account for the doctrine of inertia, which is considered to be one of Perelman's major contributions to general argumentation theory because it provides a foundation for the ascription of the burden of proof in practical discourse. ${ }^{57}$ Inertia simply refers to the presumption that, failing contrary proof, an attitude-or a particular interpretation of the law for that matter-adopted in the past will subsist, either for a desire for coherence

53 Perelman, Logique Juridique, [58], 118, [64], 125.

54 See eg Perelman and Olbrechts-Tyteca, The New Rhetoric, [18]-[19], 74-9, [34], 133-8; Perelman, 'L'usage at l'abus des notions confuses' (1978) 7 Études de logique juridique 3; Perelman, Justice, Law, and Argument, 95-106; Perelman, Realm of Rhetoric, 27-8.

55 Perelman, Justice, Law, and Argument, 98-9; Perelman, 'Peut-on fonder les droits de homme?', translated as 'Can the Rights of Man Be Founded?' in Alan Rosenbaum (ed), The Philosophy of Human Rights: International Perspectives (Aldwych Press 1981) 45.

56 On cumulation, see Perelman and Olbrechts-Tyteca, The New Rhetoric, Ch 5.

57 Alexy, A Theory of Legal Argumentation, 171-3. 
or from force of habit, and thus may be relied upon in subsequent argument. Change, on the other hand, requires justification. Perelman argues that inertia underlies the rule of formal justice, namely that what has been considered as valid in one situation will be considered valid in all similar situations. ${ }^{58}$

Because natural language is ambiguous, and because topics may be applied and interpreted in diverse ways, Perelman sees specific argumentative figures as techniques which the rhetor may exploit in the presentation of his thesis. The decision regarding which techniques to use, or manipulate, in an argument is not pre-determined. These are not automatically selected without consideration of the end in view. On the contrary, the techniques employed will be consciously chosen with the hope of maximizing the persuasive force of the argument with the audience. The bulk of The New Rhetoric and Logique juridique, as well as numerous essays, comprise the exposition of various types of argumentative techniques, structures, and figures. ${ }^{59}$ These discussions bear on such matters as pragmatic arguments, ${ }^{60}$ analogy and metaphor, ${ }^{61}$ quasi-logical arguments, ${ }^{62}$ arguments from authority, ${ }^{63}$ and so on.

Along with the choice of topic and technique, each rhetor may choose to give presence to different aspects of the argument. Presence is simply the argumentative concentration on particular factors in order to stress their importance to the audience while discounting or de-emphasizing other factors. ${ }^{64}$ The selection of data, topics, and modes of argument is inevitable in rhetoric:

choice is... a dominant factor in scientific debates: choice of the facts deemed relevant, choice of hypotheses, choice of the theories that should be confronted with the facts, choice of the actual elements that constitute facts. The method of each science implies such a choice, which is relatively stable in the natural sciences, but is much more variable in the social sciences.

By the very fact of selecting certain elements and presenting them to the audience, their importance and pertinency to the discussion are implied. Indeed, such a choice endows those elements with a presence, which is an essential factor in argumentation. ${ }^{65}$

58 Perelman and Olbrechts-Tyteca, The New Rhetoric, [27], 104-10, [52], 218-20; Perelman, Justice, Law, and Argument, 27-8; 169-71. Perelman sees inertia as allowing the transition from normal to norm by way of argumentative justification, although he concedes the validity of David Hume's view that this is a logically illicit transition: see Justice, Law, and Argument, 28. Hume's argument is in David Hume, A Treatise on Human Nature (OUP 1978: ed LA Selby-Bigg and PH Nidditch) [III.i.1], 455-70. On Hume's argument, see JL Mackie, Hume's Moral Theory (Routledge 1980) Ch 4; Perelman, Logique Juridique, [49], 99-101.

59 See eg Perelman and Olbrechts-Tyteca, The New Rhetoric, [41]-[42], 167-79, [44]-[96], 185-458; Perelman, The Idea of Justice and the Problem of Argument, 196-207; Perelman, Logique Juridique, [33], 54-9, [64]-[65], 125-7, [67]-[69], 129-32; Perelman, Realm of Rhetoric, 53-137.

60 See eg Perelman and Olbrechts-Tyteca, The New Rhetoric, [62], 266-70; Perelman, The Idea of Justice and the Problem of Argument, 196-207; Perelman, Logique Juridique, [65], 126-7.

61 See eg Perelman and Olbrechts-Tyteca, The New Rhetoric, [82]-[88], 371-410; Perelman, Logique Juridique, [68], 129-30; Perelman, Realm of Rhetoric, 114-25.

${ }_{62}$ See eg Perelman and Olbrechts-Tyteca, The New Rhetoric, [45]-[59], 193-260; Perelman, Logique Juridique, [64], 126; Perelman, Realm of Rhetoric, 53-80.

63 See eg Perelman and Olbrechts-Tyteca, The New Rhetoric, [70], 305-10.

64 See eg Perelman and Olbrechts-Tyteca, The New Rhetoric, [29], 115-20, [36] 142; Perelman, Logique Juridique, [59], 118-19; Perelman, Realm of Rhetoric, 35-6.

${ }_{65}$ Perelman and Olbrechts-Tyteca, The New Rhetoric, [29], 116. 
Argumentation is always selective and thus dependent on choice, but this necessary act of selection may be self-defeating. The emphasis inherent in presence could distract the audience, or lead the argument in an unintended or unwanted direction-for example, a rhetor may give presence to his opponent's argument by concentrating on its refutation and thus add weigh to it, especially if his counter-argument is weak. ${ }^{66}$

Choice of the elements of an argument is unavoidable because all argumentation is subject to limitation one way or another-for example by constraints of time or length. Even if this is not institutionally regulated, the audience's attention cannot be prolonged indefinitely. The fullness of a discourse is thus a question of choice, and that choice ascribes presence to specific arguments. ${ }^{67}$ However, temporal limitations cut both ways: a practical obligation is not only imposed on the rhetor(s) to compress the debate, but also the audience is required to make a decision even if none of the arguments presented seem convincing. ${ }^{68}$

\section{Rhetoric, Interpretation, and Law}

Perelman's theory of legal reasoning, 'la logique juridique', is essentially an extension of his general theory of rhetoric. Like general rhetoric, legal reasoning is centred on attaining the adhesion of the audience, rather than establishing an objective truth, and for this purpose proceeds from topics. Further, it is generally the case that the audience being addressed is a specialist audience of lawyers which has its own predispositions regarding legitimate or accepted modes of legal reasoning. Also, as the categorization of facts is dependent on the rule under which they are alleged to be subsumed, each party may stress different laws and precedents as decisive. ${ }^{69}$ A consequence of the concentration on adhesion is that the interpretation of a given text might not be disputed. At most this can only lead to the conclusion that possible alternative interpretations of the text did not interest either party because these offered neither any advantage.

Perelman's 'logique juridique', however, also has a normative component, and is geared towards domestic litigation within a legal system which observes a tripartite separation of powers. The core of his argument is that judicial decisions must be both just and in conformity with the law in force: ${ }^{70}$

The judge's mission is to speak the law but in a way that conforms to the sensibilities of society. Why? Because his role is to establish legal peace and this peace comes about only when he can convince the parties, the public and his superiors that he has adjudicated in an equitable way. ${ }^{71}$

66 Perelman and Olbrechts-Tyteca, The New Rhetoric, [98], 470, [101], 481; Perelman, Realm of Rhetoric, 141-2.

67 Perelman and Olbrechts-Tyteca, The New Rhetoric, [37], 143.

68 Perelman, Le Champ de l'argumentation, 46.

69 See Perelman and Olbrechts-Tyteca, The New Rhetoric, [8], 38; Perelman, Logique Juridique, [39], 72-4, [44], 83, [84]-[85], 158-9, [95], 174; Perelman, Justice, Law, and Argument, 129.

70 This is constantly reiterated in Perelman's work: see eg Perelman, Logique Juridique, -[38]-[39], 70-2, [46], 87, [50], 102, [71], 136-7, [87], 162, [96]-[97], 175; Perelman, Justice, Law, and Argument, 121-2, 124, 129, 143.

71 Perelman, Justice, Law, and Argument, 143. 
This aspect of his theory, because it is intrinsically tied to domestic constitutional structures ${ }^{72}$ is less germane to questions of interpretation in international law than his exposition of techniques of argumentation and rhetorical theory in general, but his application of rhetoric to legal reasoning does contain some useful additional points.

In constructing his analysis of legal reasoning, Perelman focused on the judiciary. Although he saw the judicial process as involving the dialectical opposition of the parties' claims, he restricted his field of analysis to the judicial decision, thus rejecting the view that judgments should be seen as the outcome of a process:

Pour préciser la notion de raisonnement juridique, nous entendons par cette expression le raisonnement du juge, tel qu'il se manifeste dans un jugement ou arrêt qui motive une décision. Les analyses doctrinales d'un juriste, les plaidoiries des avocats, l'acte d'accusation du ministère public, fournissent des raisons qui peuvent exercer une influence sur la décision du juge: seul le jugement motivé nous fournit l'ensemble des éléments qui nous permettent de dégager les caractéristiques du raisonnement juridique. ${ }^{73}$

There is more to legal rhetoric as a mechanism for interpretation than the judicial decision, and the context for interpretative argument in international law is not, principally, in the field of litigation. This is also the case in domestic law: few disputes end up in court. Both internationally and domestically most acts of interpretative argument will lie in activities such as advising clients, engaging in negotiations, research and the construction of academic arguments, or the presentation of a proposed text or its interpretation to non-judicial bodies. On the other hand, to a greater or lesser extent, these non-judicial uses are instrumental and may be partial, aimed at advancing a particular agenda, while one would hope that the judiciary is more disinterested in its endeavours and focused on the legal merits of the case in hand. Accordingly, Perelman's field of analysis is justifiable in order to discern 'l'ensemble des éléments', but his conclusions are capable of generalization to legal argumentation as a whole.

Perelman sees cumulation of argument as a specific characteristic of legal reasoning. If several distinct arguments lead to the same conclusion, the value the audience attributes to it, and to each argument individually, will be increased. There is little likelihood that several entirely wrong arguments could lead to the same conclusion. ${ }^{74}$ Cumulation arises simply because law is value

72 See Perelman, Logique Juridique, 'Première Partie', [15]-[48], 21-96.

73 Perelman, Droit, morale et philosophie (2nd edn, LGDJ/Pichon et Durand-Auzias 1976) 93: 'To define legal reasoning, by this term we mean judicial reasoning as disclosed in a judgment or order which justifies a decision. The doctrinal analysis of a legal commentator, the lawyers' pleadings and the indictment of the prosecutor provide reasons which might influence the judge's decision: only the reasoned judgment contains all the elements which allow us to extricate the characteristics of legal reasoning'. See also Perelman, Logique Juridique, [81], 153-4, [98], 177, noting that he concentrated particularly on the reasoning of Cours de cassation. This focus on judicial reasoning was one of the tenets of the 'Brussels School' of legal theorists which was associated with the Belgian Centre National de Recherches de Logique. Its legal section was headed by Perelman. For an account of the Brussels School, see Paul Foriers, 'L'état des recherches de logique juridique en Belgique’ (1967) 2 Études de logique juridique 23, 34-40.

74 Perelman and Olbrechts-Tyteca, The New Rhetoric, [99]-[100], 471-9; Perelman, The Idea of Justice and the Problem of Argument, 161. 
dependent, and values cannot be captured in a formal system. The application of law lies not in defining each word, but requires recourse to the values underlying the norms. This aspect is ignored if the process is assimilated to a syllogistic operation. ${ }^{75}$ Cumulation is thus required because legal argumentation is not logically compelling.

Perelman is barely prescriptive on how his theory should be applied in legal reasoning and interpretative argument. This is true of rhetorical theories generally, but is probably inevitable as all argumentation is intimately dependent on context and subject, as well as the aims of the rhetor. What rhetoric does provide is a strategy or broad structure for argumentation which has the potential to be effective, or in short, to be persuasive. Fundamental to this argumentative process is choice. Choice permeates the whole process, from the choice of the initial topic, the object of agreement the audience already accepts which the rhetor thinks is most suitable to achieve his end or is most supportive to the interpretation he proposes, through the elaboration of the argument, and the decision of what points to emphasize, and which points to refute. These choices are not free: the rhetor must exercise judgement in the identification of the audience's predispositions and decide how to adapt his argument accordingly.

Established canons of interpretation can act as topics-an obvious example is the interpretative rules set out in the VCLT. Even then, however, the opening gambit is instrumental, and thus subject to choice: should one argue that the text is clear in the light of the treaty's object and purpose; or should it be read in the light of the parties' subsequent practice; or that recourse should be made to the travaux préparatoires to clarify matters? This can only be a matter of choice- the decision of what is the best and most effective way to try to persuade. General propositions such as the VCLT interpretative rules might perhaps, as Durham suggests, best be seen as meta-topoi, as over-arching argumentative structures which only gain substance once more specific topics are adduced, such as the adverse party's prior practice, its interpretative views expressed in official statements to international organizations or conferences, or in diplomatic démarches, or even in statements to the press.

Rhetorical theory, however, offers no certainties in interpretation-by definition, it seeks to explicate non-constraining argument. It offers ideas of topics, tropes, and types of argumentation, but no sure solutions. All depends on context and the audience. It offers little guidance on the inherent strength of interpretative arguments, and how strong arguments may be differentiated from the weak. The strength of an argument is ultimately centred on the intensity of the audience's initial adhesion and its subsequent persuasion. All that Perelman says is that if the audience adheres to ascertained presuppositions and methodological rules, then the inadequacy of some arguments can be identified. Even then, there is no certainty that an argument can be persuasive in its totality: the audience retains its

75 Perelman, Logique Juridique, [24], 34-6, [31], 52, [34], 59, [37], 67-70, [49], 99-100; Perelman, Justice, Law, and Argument, 140-1, 143-4, 150, 154, 160. 
power of appraisal and decision. ${ }^{76}$ One can only conclude that a 'strong' argument is one that the audience accepts, but this is only trivially true. Successful arguments can only be determined situationally, and ex post facto. Given the recounting of specific argumentative figures which constitutes a great part of Perelman's work, one is left with the impression that he was intent on providing something akin to an array of styles and samples while failing to provide detailed instructions for their use. Alexy has argued that there is a measure of truth in the view that a topic is a reasonable or generally accepted proposition used as an argumentative premise. He comments, however, that this is too general because it fails to differentiate between the different types of legal material which might be used, and the role they play in the construction of an argument. ${ }^{77}$

Perelman's topical approach is also open to the objection that it presents law as asystemic. It concentrates on dealing with legal disputes and questions of interpretation episodically and instrumentally, and fails to systematize legal material. Any systematizing function that topics possess becomes subservient to situational acts of persuasion, and Perelman pays no attention to the role topics play in the justification of the decision. In Perelmanien theory, topics can only be persuasive. They cannot be binding because this would make the theory self-contradictory because Perelman denies that legal reasoning can ever be deductive. In particular, when he considers international law, he thinks that discussion is open-ended:

The recourse to confused notions which is sometimes indispensable in internal law proves to be completely inevitable in public international law when the confusion of notions is an indispensable condition for achieving agreement on a text between States having different, if not incompatible, ideologies. ${ }^{78}$

This goes too far. Instruments may be entered into between states which share a world view and, to be honest, states also have different bargaining strengths and one (or some) may effectively impose a text on others-either because it has the whiphand on an issue, or because the others are willing to compromise their interests in order to establish a text which they hope will ensure the participation of another. We might term this the 'League of Nations syndrome', the fear that some institution or convention will fail to be effective unless state $\mathrm{X}$ is part of it.

Further, every act of interpretation precludes others. In terms of Perelman's own theory, once an interpretation is made, it takes on inertia and that interpretation needs no further justification in the future. It becomes a topic itself for future arguments, and only a changed interpretation will require justification. Through interpretation, abstract values thus become concrete, and as interpretations and practice coalesce around an issue, the point will be reached when 'a mass of opinions [become] an ordered system'. ${ }^{79}$ This does not mean that the legal system is

76 Perelman, Champ de l'argumentation, 114-15, 126; Perelman, Logique Juridique, [95], 174; Perelman, Justice, Law, and Argument, 129; Perelman, Realm of Rhetoric, 139-40.

77 Alexy, $A$ Theory of Legal Argumentation, 20-4.

78 Perelman, Justice, Law, and Argument, 98-9.

79 Stoljar, 'System and Topoi', 389. 
transformed into an axiomatically oriented Cartesian system where logic is substituted for rhetoric. There is still room for argument:

Often... what one finds in the 'topoi catalogues' are divergent strands of reasoning and factual settings more or less analogous to the case to be resolved. Great lawyering at this point requires ingenuity and insight. The process of weaving persuasive arguments, either as an advocate or a judge, is a creative and constitutive exercise, even if ultimately the objective is to exhibit fidelity to statutes and precedents. ${ }^{80}$

\section{The Value of Rhetoric}

In playing the interpretation game, much depends on the skill of the rhetor and the rhetorical choices he makes. Rhetoric can provide the method and the technique by which interpreters achieve the object of securing the audience's adherence to their argumentative stance, but even a skilled rhetor cannot guarantee a successful outcome. Rhetoric is an art, not a science. Although rhetorical theory contains ground rules for persuasive argument-start from a topic which is an object of agreement, pay attention to the audience's pre-conceptions, including its understanding of legitimate or proper argumentative methods, adapt the argument to the audience-how the array of cards rhetoric provides is played depends on choice. Aristotelian rhetoric, and the theories it has inspired, aims to set out and explain guidelines for persuasive and reasoned argument. Nevertheless, the pejorative impressions associated with the Sophists have always remained attached to rhetoric. There has always been the lingering suspicion that it is merely a technique for the manipulation of societies, groups, or individuals by rabble-rousers, by demagogues, or by those who can simply speak well:

Thanks in no small part to Platonic critique of the Sophists and rhetoricians of ancient Greece, rhetoric... has enjoyed a less than stellar reputation in the history of philosophy. In some respects, rhetoric has contributed to its own demise by paying excessive attention to surface issues of ornamentation and eloquence to the detriment of issues of substance. Moreover, its reputation, like that of lawyers, has suffered from a meretricious tendency toward promiscuous service of all causes. ${ }^{81}$

Like lawyers in popular consciousness, the art of rhetoric seems to be in need of some rehabilitation.

80 Viehweg, Topics and the Law, xxiv (translator's note).

81 Viehweg, Topics and the Law, xiii-xiv (translator's foreword). 